\title{
A spore-lytic enzyme released from Bacillus cereus spores during germination
}

\author{
Shio Makino, Norihito Ito, Toshihiko Inoue, Shigeru Miyata \\ and Ryuichi Moriyama
}

Author for correspondence: Shio Makino. Tel: +810527894132 ext. 6801. Fax: +810527894012.

Department of Applied Biological Science, School of Agricultural Science, Nagoya University, Nagoya, Aichi, 464-01, Japan

\begin{abstract}
The exudate of fully germinated spores of Bacillus cereus IFO 13597 in $0.25 \mathrm{M}$ sodium phosphate buffer, pH 7.0, was found to contain a spore-lytic enzyme. This enzyme was found to cause loss of absorbance in coat-stripped spore suspensions and phase-darkening of the spores but had minimal activity on isolated peptidoglycan substrates. The enzyme was purified in an active form and identified as a $24 \mathrm{kDa}$ protein which is either an amidase or a peptidase. The amino-terminal 19 residues had the following sequence:

FSNQVIQRGASGEKVIELQ. The spore-lytic enzyme retained its activity in a medium of a relatively high ionic strength containing a non-ionic surfactant such as nonaethyleneglycol n-dodecyl ether. This activity was optimum at a salt concentration of about $30 \mathrm{mM}$ in assay buffer at neutral pH. In contrast to the enzyme in a spore-bound form, the enzyme in solution was shown to be heat-sensitive and was readily inactivated by thiol reagents.
\end{abstract}

Keywords: Bacillus cereus, spore-lytic enzyme, germination cortex hydrolysis

\section{INTRODUCTION}

The cortical peptidoglycan has been strongly implicated in the maintenance of bacterial spore dormancy. The degradation of peptidoglycan in the spore cortex is an essential event in spore germination (Foster \& Johnstone, 1990 ) and the mechanism of cortex hydrolysis is crucial to an understanding of the germination pathway. A number of spore-lytic enzymes have been isolated from bacterial spores of different origins (Ando, 1979; Brown \& Cuhel, 1975; Brown et al., 1978, 1982; Foster \& Johnstone, 1987; Gombas \& Labbe, 1981, 1985; Gould et al., 1966; Tang \& Labbe, 1987). However, in most cases, their involvement in germination has not been unequivocally established.

Bacillus cereus spores contain four separate spore-degrading enzymes (Warth, 1972) and spore-lytic enzyme activities are localized in both the core and the coat fraction (Brown \& Cuhel, 1975; Brown et al., 1978). Brown et al. extracted a surface-bound spore-lytic enzyme by urea/mercaptoethanol or guanidine $\mathrm{HCl} /$ mercaptoethanol treatment (Brown \& Cuhel, 1975; Brown et al., 1978, 1982). The enzyme did not induce refractility changes in coatdamaged spores following treatment with this enzyme.

Abbreviations: $C_{12} E_{9}$, nonaethyleneglycol $n$-dodecyl ether; DFP, diisopropylfluorophosphate; NAM, $\mathrm{N}$-(9-acridinyl)maleimide; NEM, $\mathrm{N}$-ethylmaleimide; PCMB, p-chloromercuribenzoate; PNAG, $p$-nitrophenyl- $N$ acetyl- $\beta$-D-glucosamide; TFA, trifluoroacetic acid.
However, Gould et al. (1966) found a spore-lytic enzyme which was liberated from a spore-bound form during germination when the ionic strength of the medium was high. The enzyme causes loss of absorbance in coatstripped spore suspensions and phase-darkening of the spores. These changes are characteristic of normal spore germination. This suggests that the enzyme is involved in the germination pathway. However, the enzyme has not been characterized on a molecular level. In this study we found that a spore-lytic enzyme is released from germinating $B$. cereus IFO 13597 spores into the germination exudate. Furthermore, the enzyme causes refractility changes of coat-stripped spores, and is similar to the enzyme characterized by Gould et al. (1966). This report deals with the purification and the partial characterization of the enzyme.

\section{METHODS}

Preparation of spores. Spores of B. cereus IFO 13597 were prepared in the following manner. Portions $(1 \mathrm{ml})$ of a nutrient broth culture were inoculated on the surface $\left(600 \mathrm{~cm}^{2}\right)$ of a sporulation medium $\left(1^{-1}\right.$ Bact-peptone $5 \mathrm{~g}$, meat extract $3 \mathrm{~g}$, yeast extract $1 \mathrm{~g}, \mathrm{MnSO}_{4} 0.1 \mathrm{~g}$, agar $15 \mathrm{~g}, \mathrm{pH} 7 \cdot 0$ ) in culture flasks and incubated at $32^{\circ} \mathrm{C}$ for $3 \mathrm{~d}$. The spores were harvested and washed five times with distilled water. Spores were then incubated in 10 vols $2 \mathrm{M} \mathrm{KCl}, 10 \mathrm{mM}$ sodium phosphate, $\mathrm{pH} 7 \cdot 5$, at $37^{\circ} \mathrm{C}$ for $40 \mathrm{~min}$ and washed twice with water. Afterwards, the spores were further incubated at $37^{\circ} \mathrm{C}$ for $30 \mathrm{~min}$ in 10 vols $2 \mathrm{M}$ urea, $5 \mathrm{mM}$ CHES, pH 9.3, containing 
$25 \mathrm{mM}$ 2-mercaptoethanol. After washing five times with water, the spores were stored at $4{ }^{\circ} \mathrm{C}$. Spores of Clostridium perfringens S40 and of Bacillus stearothermophilus IAM 1035 were prepared according to the methods of Ando \& Tsuzuki (1984) and of Tomida et al. (1991), respectively.

Preparation of coat-stripped spores, isolation of cortical fragments and isolation of the vegetative cell wall. Removal of the spore coat from B. cereus and B. stearotbermophilus spores was performed with a slight modification of the method of Gombas \& Labbe (1981). Spores were treated with $30 \mathrm{mM}$ SDS, 0.2 M 2-mercaptoethanol, $0.1 \mathrm{M}$ borate buffer, $\mathrm{pH} 10 \cdot 0$, at $40^{\circ} \mathrm{C}$. B. cereus and B. stearotbermophilus spores were treated for 8 and $4 \mathrm{~h}$, respectively. Both were extensively washed with distilled water. Coat-stripped spores of $\mathrm{Cl}$. perfringens were prepared according to the method of Ando \& Tsuzuki (1984).

Spores or vegetative cells collected from a stationary-phase culture were suspended in distilled water and disrupted at $0-4{ }^{\circ} \mathrm{C}$ in a bead-beater (Edmund Buhler) with glass beads (diam. $0 \cdot 1 \mathrm{~mm}$ ). Spore cortical fragments and cell walls were isolated according to the methods of Tang \& Labbe (1987) and of Kuroda \& Sekiguchi (1990), respectively.

Germination. A suspension of $B$. cereus spores $[0 \cdot 1 \mathrm{~g}$ packed spores $(\mathrm{ml} \text { water })^{-1}$ ] was heat-activated at $65^{\circ} \mathrm{C}$ for $45 \mathrm{~min}$ and cooled on ice. After sedimentation by centrifugation $(6000 \mathrm{~g}$, $10 \mathrm{~min}, 4^{\circ} \mathrm{C}$ ), the spores were germinated at $32^{\circ} \mathrm{C}$ in $10 \mathrm{vols}$ $0.25 \mathrm{M}$ sodium phosphate germination buffer containing $10 \mathrm{mM}$ L-alanine and $4 \mathrm{mM}$ adenosine, $\mathrm{pH} 7 \cdot 0$. Germination was followed by monitoring the decrease in $\mathrm{OD}_{600}$ of spore suspension and phase-darkening of the spores. A Jasco UV5 spectrophotometer was used. In some experiments, spores were germinated in the presence of chloramphenicol $\left(100 \mu \mathrm{g} \mathrm{ml}^{-1}\right)$.

Spore-lytic enzyme assay. Spore-lytic enzyme activity was assayed by measuring the decrease in $\mathrm{OD}_{600}$ of coat-stripped spore suspensions in a cell of $1 \mathrm{~mm}$ light path at $32^{\circ} \mathrm{C}$. A Jasco UV5 spectrophotometer was used. The reaction mixture contained coat-stripped spores $\left(\mathrm{OD}_{600}\right.$ of $\left.0 \cdot 1\right)$ and the enzyme in a final volume of $150 \mu \mathrm{l}$ of $30 \mathrm{mM}$ sodium phosphate buffer, $\mathrm{pH} 7 \cdot 0$, containing $1 \mathrm{mM}$ EDTA, $1 \mathrm{mM}$ sodium thioglycollate and $0.1 \% \mathrm{C}_{12} \mathrm{E}_{9}$ (Nikko Chemicals). One unit of activity is defined as a decrease in $\mathrm{OD}_{600}$ of $0.1 \mathrm{~min}^{-1}$. At the same time, activity was qualitatively examined through microscopic observation of the change from phase-bright coat-stripped spores to phase-dark ones.

Purification of spore-lytic enzyme from germination exudate. A typical purification procedure was as follows. Packed spores $(5 \mathrm{~g})$ were incubated in $50 \mathrm{ml}$ germination buffer at $32^{\circ} \mathrm{C}$ for $45 \mathrm{~min}$. After centrifugation $\left(8000 \mathrm{~g}, 10 \mathrm{~min}, 4^{\circ} \mathrm{C}\right)$, the supernatant fluid $(50 \mathrm{ml})$ was brought to $0.1 \% \mathrm{C}_{12} \mathrm{E}_{9}$ and $0.2 \mathrm{mM}$ PMSF. The fluid was dialysed at $4{ }^{\circ} \mathrm{C}$ for $24 \mathrm{~h}$ against 21 of $75 \mathrm{mM}$ sodium phosphate buffer, $\mathrm{pH} 7 \cdot 0$, containing $1 \mathrm{mM}$ EDTA, $1 \mathrm{mM}$ sodium thioglycollate and $0 \cdot 1 \% \mathrm{C}_{12} \mathrm{E}_{9}$ (buffer $\mathrm{A}$ ). The dialysed solution was centrifuged $(16000 \mathrm{~g}, 30 \mathrm{~min}$, $\left.4{ }^{\circ} \mathrm{C}\right)$ and applied to a SP-Sephadex C-25 column $(1.5 \times 15 \mathrm{~cm}$, Pharmacia), which had been equilibrated with buffer $A$. After the column had been washed with buffer $A$, adsorbed materials were eluted at $4{ }^{\circ} \mathrm{C}$ with a $160 \mathrm{ml}$ linear gradient of up to $0.4 \mathrm{M}$ $\mathrm{NaCl}$ in buffer A. Fractions containing spore-lytic activity, which were eluted at a $\mathrm{NaCl}$ concentration between $0 \cdot 1 \mathrm{M}$ and $0.2 \mathrm{M}$, were pooled $(35 \mathrm{ml})$. The eluate was immediately applied to a BSA-Sepharose $4 \mathrm{~B}$ column $(2.2 \times 8 \mathrm{~cm}$, prepared by a coupling of BSA with $\mathrm{BrCN}$-activated Sepharose $4 \mathrm{~B}$ ) at $4{ }^{\circ} \mathrm{C}$, which had been equilibrated with buffer $A$. The column was washed at $4^{\circ} \mathrm{C}$ with $10 \mathrm{ml} 0.4 \mathrm{M} \mathrm{NaCl}, 75 \mathrm{mM}$ sodium phosphate buffer, $\mathrm{pH} 7 \cdot 0$, containing $1 \mathrm{mM}$ EDTA, $1 \mathrm{mM}$ sodium thioglycollate and $1 \%(\mathrm{v} / \mathrm{v}) \mathrm{C}_{12} \mathrm{E}_{9}$, and then with $40 \mathrm{ml}$ buffer A containing $0.2 \mathrm{M} \mathrm{NaCl}$. The column was kept at $20^{\circ} \mathrm{C}$ for $1 \mathrm{~h}$; the enzyme activity was then recovered by eluting at $20^{\circ} \mathrm{C}$ with $50 \mathrm{ml}$ buffer A containing $0 \cdot 2 \mathrm{M} \mathrm{NaCl}$. Fractions containing enzyme activity were pooled $(35 \mathrm{ml})$ and dialysed at $4^{\circ} \mathrm{C}$ for $24 \mathrm{~h}$ against $1175 \mathrm{mM}$ sodium phosphate buffer, $\mathrm{pH} 6.5$, containing $0.1 \% \mathrm{C}_{12} \mathrm{E}_{9}$ (buffer $\mathrm{B}$ ). The dialysed solution was applied at $20^{\circ} \mathrm{C}$ to a MCI GEL CQK-30S column $(7.5 \times 75 \mathrm{~mm}$, a high performance liquid chromatography column with a sulfopropyl group as an ion exchanger; Mitsubishi Kasei) pre-equilibrated with buffer B. After the column was washed with buffer $B$, proteins were eluted at $20^{\circ} \mathrm{C}$ with a linear gradient of $0-0.4 \mathrm{M} \mathrm{NaCl}$ in buffer $\mathrm{B}$. The flow rate was $0.5 \mathrm{ml} \mathrm{min}^{-1}$ and the eluate was monitored by measuring $A_{220}$. Fractions $(0.75 \mathrm{ml}$ each) were collected and assayed for enzyme activity.

Active fractions were further chromatographed on a $\mu$ Bondasphere cyanopropyl-300A column $(3.9 \times 150 \mathrm{~mm}$, Waters $)$ which had been equilibrated with $5 \%(\mathrm{v} / \mathrm{v})$ acetonitrile/ $0.05 \%$ TFA, and eluted with a linear gradient of $5 \%$ acetonitrile $/ 0.05 \%$ TFA and $60 \%$ acetonitrile $/ 30 \%(\mathrm{v} / \mathrm{v})$ 2 -propanol $/ 0.05 \%$ TFA. The enzyme lost its activity in this purification step. The $24 \mathrm{kDa}$ protein eluted as a major component was used for $\mathrm{N}$-terminal amino acid sequence analysis and preparation of antibodies.

Preparation of antiserum and immunoprecipitation. A mouse was intraperitoneally injected with $10 \mu$ cyanopropyl columnpurified $24 \mathrm{kDa}$ protein emulsified in Freund's complete adjuvant. After 3 weeks, the mouse was injected with the same amount of protein in Freund's incomplete adjuvant. A second boost was performed 5 weeks later, and the mouse was bled $10 \mathrm{~d}$ later, after the final injection. The blood was brought to $0.15 \mathrm{M}$ $\mathrm{NaCl}, 5 \mathrm{mM}$ sodium phosphate, $0.1 \% \mathrm{NaN}_{3}, \mathrm{pH} 7 \cdot 0$, via the addition of a concentrated buffer and then stored at $4{ }^{\circ} \mathrm{C}$ for $20 \mathrm{~h}$. After centrifugation $\left(14000 \mathrm{~g}, 5 \mathrm{~min}, 4^{\circ} \mathrm{C}\right)$, the antiserum was stored at $-20^{\circ} \mathrm{C}$.

For immunoprecipitations, the antiserum $(50 \mu \mathrm{l})$, or nonimmune control serum of the immunized mouse $(50 \mu \mathrm{l})$, was incubated with $100 \mu \mathrm{l}$ protein $\mathrm{A}$-agarose (Pharmacia) at $4{ }^{\circ} \mathrm{C}$ for $16 \mathrm{~h}$. After centrifugation $\left(5000 \mathrm{~g}, 5 \mathrm{~min}, 4^{\circ} \mathrm{C}\right)$, the gel was washed with a $1.5 \mathrm{M}$ glycine- $\mathrm{NaOH}$ buffer, $\mathrm{pH} 7 \cdot 0$, containing $3 \mathrm{M} \mathrm{NaCl}$, and equilibrated with buffer A. The spore-lytic enzyme ( $100 \mu \mathrm{l}, 0.35$ units), partially purified by a BSASepharose 4B column, was mixed with serum-treated protein Aagarose gels. This mixture was incubated at $4{ }^{\circ} \mathrm{C}$ for $16 \mathrm{~h}$. After centrifugation $\left(6000 \mathrm{~g}, 5 \mathrm{~min}, 4^{\circ} \mathrm{C}\right)$, the spore-lytic activity and the protein of the supernatant were examined.

Mode of action of the spore-lytic enzyme. A coat-stripped spore suspension $(1.2 \mathrm{ml}$ in $30 \mathrm{mM}$ sodium phosphate buffer, $\mathrm{pH} 7 \cdot 0$, containing $1 \mathrm{mM}$ EDTA, $1 \mathrm{mM}$ sodium thioglycollate, and $0.1 \% \mathrm{C}_{12} \mathrm{E}_{9}$, with an $\mathrm{OD}_{600}$ of 1.4 in a cell of $1 \mathrm{~mm}$ light path) was incubated with the enzyme $(50 \mu \mathrm{l}, 2 \cdot 7$ units $)$ at $32^{\circ} \mathrm{C}$. The change in $\mathrm{OD}_{600}$ was then monitored. After hydrolysis $(30 \mathrm{~min})$, the suspension was centrifuged $\left(8000 \mathrm{~g}, 10 \mathrm{~min}, 4^{\circ} \mathrm{C}\right)$. The free amino groups and reducing sugars of the supernatant were determined. A control experiment was performed with the enzyme boiled for $10 \mathrm{~min}$.

Analytical methods. Protein concentrations were determined according to the methods of Lowry and/or Groves et al. (1968), using BSA as a standard. Free amino groups were identified by their reactions with trinitrobenzenesulfonate using $\mathrm{L}$-alanine as a standard, according to the method of Fields (1972). Reducing sugars were determined by the ferricyanide reduction method of Park \& Johnson (1949), using $N$-acetyl-D-glucosamine as a standard. SDS-PAGE was carried out on $12.5 \%$ or $13.3 \%$ $(\mathrm{w} / \mathrm{v})$ slab gels using a Laemmli buffer system (Laemmli, 1970) at a constant current of $20 \mathrm{~mA}$. Proteins were silver-stained 
(Oakley et al., 1980). Sequencing of $\mathrm{N}$-terminal amino acids was carried out on an Applied Biosystems 477A/120A sequence analyser.

\section{RESULTS}

\section{Action of spore-lytic enzyme released during germination on spores and isolated peptidoglycan}

Coat-stripped spores were phase-bright, but did not respond to germinants such as L-alanine, adenosine, inosine or a mixture thereof. This suggested that the spores were non-viable. When incubated with the germination exudate of $B$. cereus, the coat-stripped spores became phase-dark as the extinction of the suspensions decreased. The response was quite similar to changes characteristic of normal spore germination. However, the enzyme did not cause germination of spores which had not previously been coat-stripped. The release of the enzyme occurred in the presence of chloramphenicol, an inhibitor of protein synthesis, suggesting that the enzyme

Table 1. Lytic activity of the germination exudate for a variety of substrates

The lytic activity was measured by the decrease in $\mathrm{OD}_{600}$. The control value $(0 \cdot 25$ units for coat-stripped B. cereus spores) was taken as $100 \%$. Values were rounded off to integers. These data represent the mean of three independent experiments (SD $<12 \%$ of the mean). The same substrate specificities were also observed when the BSA-Sepharose $4 \mathrm{~B}$ column-purified enzyme was used.

\begin{tabular}{|lc|}
\hline Substrate & $\begin{array}{c}\text { Lytic } \\
\text { activity } \\
\text { (percentage } \\
\text { of control) }\end{array}$ \\
\hline Normal B. cereus spore & $<1$ \\
Coat-stripped B. cereus spore & 100 \\
Coat-stripped B. stearothermophilus spore & 65 \\
Coat-stripped $C l$. perfringens spore & 56 \\
Isolated B. cereus spore cortex & $<1$ \\
Isolated B. cereus cell wall & $<1$ \\
Isolated $C l$. perfringens cell wall & $<1$ \\
\hline
\end{tabular}

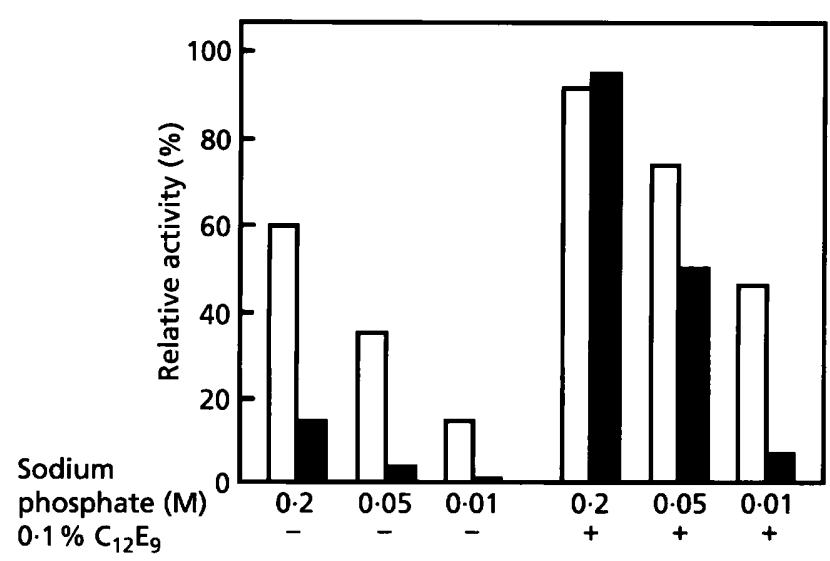

Fig. 1. Effects of sodium phosphate and $C_{12} E_{9}$ on spore-lytic enzyme activity. The germination exudates $(1 \mathrm{ml}$ each) were dialysed for $24 \mathrm{~h}$ at $4{ }^{\circ} \mathrm{C}$ against $50 \mathrm{ml}$ of the indicated concentration of sodium phosphate buffer, $\mathrm{pH} \mathrm{7.0,} \mathrm{containing}$ $1 \mathrm{mM}$ EDTA and $1 \mathrm{mM}$ sodium thioglycollate, with $(+)$ or without (-) $0.1 \% \mathrm{C}_{12} \mathrm{E}_{9}$. The activities of dialysed exudates were measured (open bars). After the dialysed exudates were stored at $4{ }^{\circ} \mathrm{C}$ for $48 \mathrm{~h}$, the activities were again measured (solid bars). Values are expressed as activity relative to that of the germination exudate before dialysis and are the means of two determinations in a representative experiment (SD $<11 \%$ of the mean). Repeated experiments gave similar results.

is not synthesized de novo during germination. Table 1 shows lytic activity of the germination exudate for a variety of substrates. Under our experimental conditions used here, changes in the extinction of coat-stripped spore suspensions were completed within $10 \mathrm{~min}$. However, the exudate did not cause a detectable loss in OD of isolated spore cortex and isolated cell wall suspensions during incubation for $1 \mathrm{~h}$.

\section{Stability of spore-lytic enzyme activity}

It was found that subtilisin-like protease activity is presented at the spore surface, which could not be removed from spores by washing with water. When protease-carrying spores were germinated, spore-lytic activity released into the germination exudate rapidly declined. This is most likely due to proteolytic degra-

\section{Table 2. Purification of the spore-lytic enzyme}

The spore-lytic enzyme was purified from 5.0 g packed weight of spores as described in Methods. ND, Not determined.

\begin{tabular}{|c|c|c|c|c|c|}
\hline Procedure & $\begin{array}{c}\text { Total } \\
\text { activity } \\
\text { (units) }\end{array}$ & $\begin{array}{c}\text { Total } \\
\text { protein } \\
\text { (mg) }\end{array}$ & $\begin{array}{c}\text { Specific } \\
\text { activity } \\
\text { [units (mg } \\
\text { protein) }{ }^{-1} \text { ] }\end{array}$ & $\begin{array}{c}\text { Yield } \\
\text { (percentage } \\
\text { total } \\
\text { original } \\
\text { activity) }\end{array}$ & $\begin{array}{l}\text { Purification } \\
\text { factor }\end{array}$ \\
\hline Germination exudate & 2445 & $45 \cdot 0$ & $54 \cdot 3$ & 100 & 1 \\
\hline SP-Sephadex C- 25 column & 1338 & $0 \cdot 94$ & $1423 \cdot 4$ & $54 \cdot 7$ & $26 \cdot 2$ \\
\hline BSA-Sepharose 4B column & 512 & ND & ND & $20 \cdot 9$ & ND \\
\hline MCI GEL CQK-30S column & 428 & $0 \cdot 028$ & $15285 \cdot 7$ & $17 \cdot 5$ & $281 \cdot 5$ \\
\hline
\end{tabular}


(a)

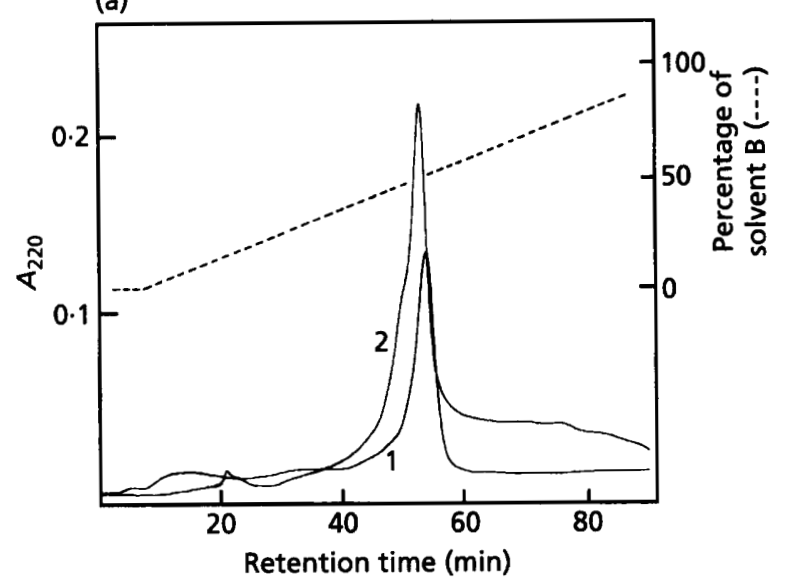

(b)

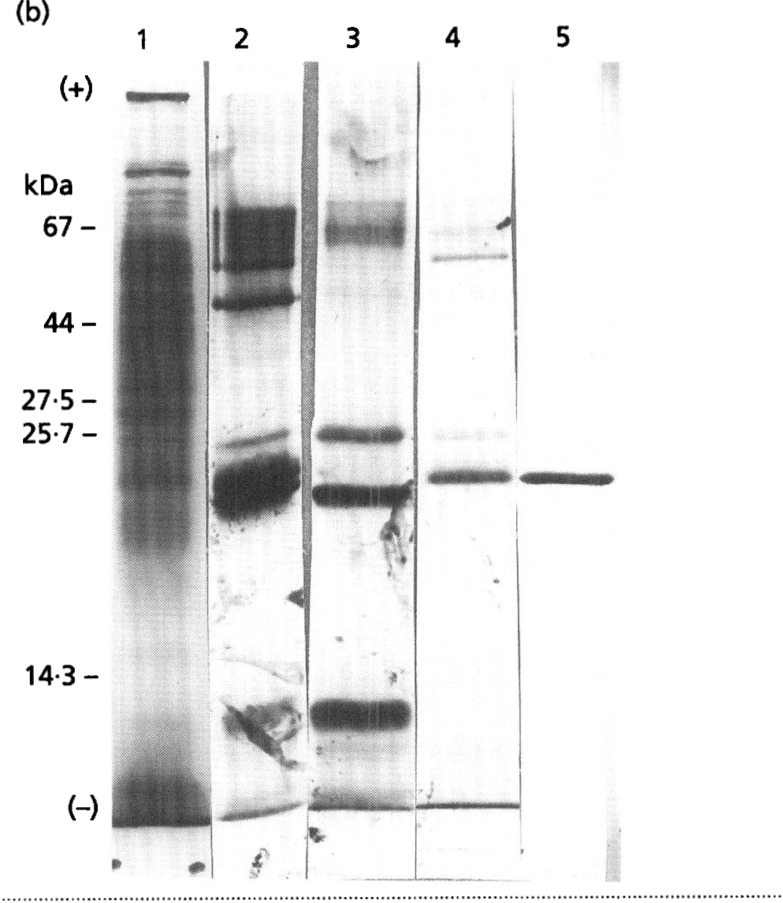

Fig. 2. Chromatography of spore-lytic enzyme on a MCI GEL CQK-30S column and SDS-gel electrophoretic profiles showing purification of the enzyme. (a) Fractions retarded on a BSASepharose 4B column which contain spore-lytic activity $(30 \mathrm{ml}$, from $4 \mathrm{~g}$ packed spores) and fractions unretarded on the column $(40 \mathrm{ml})$ were applied to a $\mathrm{MCl}$ GEL CQK-30S column. The elution profiles are shown in curves 1 and 2 , respectively. Proteins were monitored by $A_{220}$. (b) The spore-lytic enzyme was purified as described in Table 2 and analysed by $0.1 \%$ SDS$12.5 \%$ PAGE. Lanes: 1 , germination exudate; 2 , components containing the spore-lytic activity eluted from a SP-Sephadex C-25 column; 3 , components unretarded on a BSA-Sepharose 4B column; 4, components retarded on a BSA-Sepharose 4B column which contain spore-lytic enzyme activity; $5, \mathrm{MCl}$ GEL CQK-30S column-purified spore-lytic enzyme [a major peak fraction of curve 1 in (a)]. Approximately $3-30 \mu \mathrm{g}$ of proteins were electrophoresed. Migration positions of standard proteins are indicated; BSA (67000), ovalbumin (44000), subtilisin BPN' (27500), chymotrypsinogen (25700) and lysozyme (14300).

dation. The protease activity was removed ( $>98 \%$ ) from spores by washing with $2 \mathrm{M} \mathrm{KCl}$ and $2 \mathrm{M}$ urea, and the residual protease was completely inactivated by heat- (a)

(b)

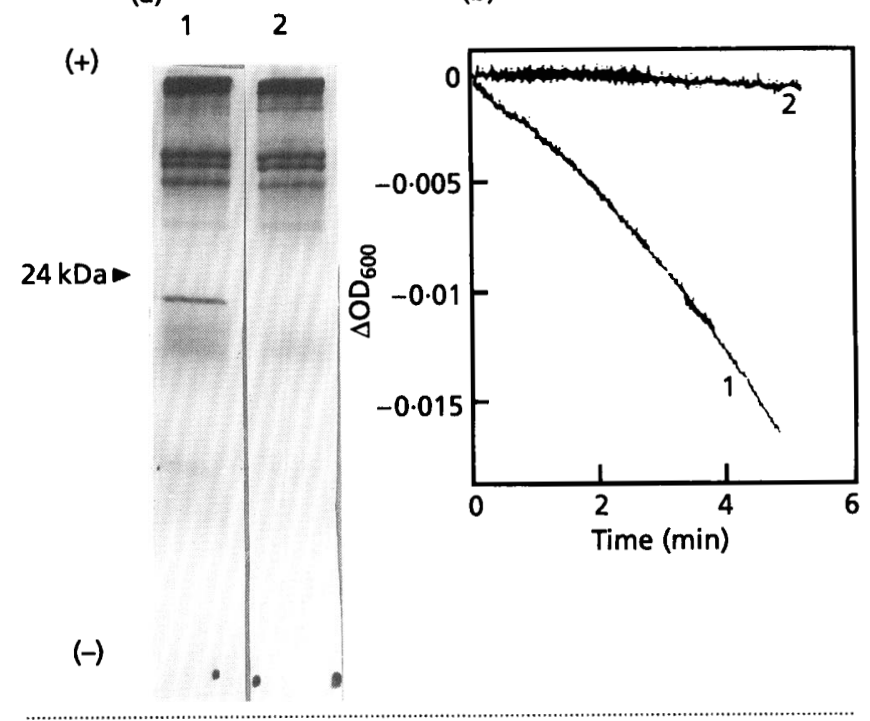

Fig. 3. Immunoprecipitation of the spore-lytic enzyme with anti-24 kDa protein antibody. Spore-lytic enzyme $(100 \mu \mathrm{l}, 0.35$ units, partially purified by BSA-Sepharose 4B column chromatography) was incubated with protein A-agarose gels which were treated with antiserum or control serum as described in Methods. After the suspensions were centrifuged, proteins in the supernatants were analysed by SDS-PAGE and enzyme activities of the supernatant were measured. (a) SDSPAGE was run on a $13.3 \% \mathrm{gel}$ and $60 \mu \mathrm{l}$ of the supernatant was electrophoresed. Lanes: 1, supernatant treated with control serum; 2, supernatant treated with antiserum. The arrow indicates the $24 \mathrm{kDa}$ protein. (b) Changes in $O_{600}$ of coatstripped spore suspensions (initial $O D_{600}$ was 0.1 in a cell of $1 \mathrm{~mm}$ light path) by the addition of supernatants $(15 \mu \mathrm{l}$ supernatant/150 $\mu \mathrm{l}$ spore suspension). Curve 1 , supernatant treated with control serum; curve 2, supernatant treated with antiserum.

treatment of the spores (incubation at $65^{\circ} \mathrm{C}$ for $45 \mathrm{~min}$ ) and the addition of PMSF to the germination exudate. However, the spore-lytic enzyme obtained from spores treated in this manner gradually lost its activity during storage. None of the protease inhibitors tested [PMSF, diisopropylfluorophosphate (DFP), leupeptin, pepstatin, chymostatin, antipain, $N$-tosyl-L-phenylalanyl chloromethyl ketone and $N$-tosyl-L-lysyl chloromethyl ketone] protected the enzyme from inactivation, suggesting the existence of a factor(s) other than proteases which inactivate(s) the spore-lytic enzyme.

As shown in Fig. 1, spore-lytic enzyme activity was found to decrease with lowering of the ionic strength of the buffer. Addition of the non-ionic surfactant $\mathrm{C}_{12} \mathrm{E}_{9}$, markedly suppressed the loss of enzyme activity. Therefore, purification of the spore-lytic enzyme was performed in a buffer of relatively high ionic strength, $>75 \mathrm{mM}$, containing $0 \cdot 1 \% \mathrm{C}_{12} \mathrm{E}_{9}$.

\section{Purification, $\mathbf{N}$-terminal amino acid sequence and mode of action of spore-lytic enzyme}

The steps in the purification procedure and the yields obtained for the spore-lytic enzyme are shown in Table 2. The spore-lytic enzyme was separated from most protein 

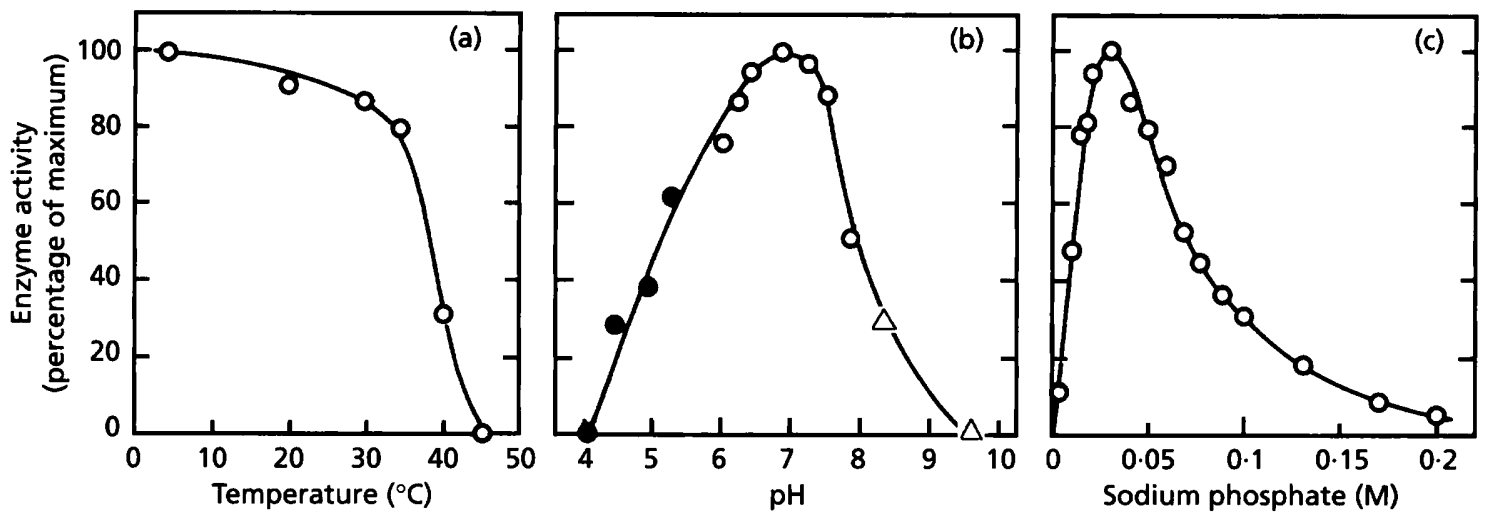

\begin{abstract}
Fig. 4. Effects of temperature, $\mathrm{pH}$ and sodium phosphate concentration on spore-lytic enzyme activity. Spore-lytic enzyme ( 0.4 units), partially purified by a BSA-Sepharose $4 B$ column, was used and the activity is shown as a percentage of the maximum. Values are the mean of two determinations in a representative experiment ( $5 D<10 \%$ of the mean). Repeated experiments gave similar results. (a) The enzyme $(15 \mu \mathrm{l})$ was mixed with $130 \mu \mathrm{l} 0.15 \mathrm{M} \mathrm{NaCl}, 75 \mathrm{mM}$ sodium phosphate buffer, $\mathrm{pH} 7.0$, containing $0.1 \% \mathrm{C}_{12} \mathrm{E}_{9}, 1 \mathrm{mM}$ EDTA and $1 \mathrm{mM}$ sodium thioglycollate, and incubated for $10 \mathrm{~min}$ at the temperatures indicated. Substrate $(5 \mu \mathrm{l})$ was then added and the activity was assayed at $32{ }^{\circ} \mathrm{C}$. (b) The enzyme $(15 \mu \mathrm{l})$ was mixed with $130 \mu \mathrm{l} 0.11 \mathrm{M}$ buffer solutions containing $0.1 \% \quad \mathrm{C}_{12} \mathrm{E}_{9}, 1 \mathrm{mM}$ EDTA and $1 \mathrm{mM}$ sodium thioglycollate, to obtain the indicated $\mathrm{pH}$. After incubation at $32^{\circ} \mathrm{C}$ for $10 \mathrm{~min}, 5 \mu \mathrm{l}$ of the substrate was added and the enzyme activity was measured. The following buffers were used: sodium acetate buffer $(\Theta)$, sodium phosphate buffer (O) and sodium carbonate buffer $(\Delta)$. (c) The enzyme $(15 \mu \mathrm{l})$ was mixed with $130 \mu \mathrm{l}$ of the indicated concentration of sodium phosphate buffer, $\mathrm{pH} 7 \cdot 0$, containing $0.1 \% \mathrm{C}_{12} \mathrm{E}_{9}, 1 \mathrm{mM}$ EDTA and $1 \mathrm{mM}$ sodium thioglycollate. After incubation at $32^{\circ} \mathrm{C}$ for $10 \mathrm{~min}, 5 \mu \mathrm{l}$ of substrate was added and the enzyme activity was assayed at $32{ }^{\circ} \mathrm{C}$.
\end{abstract}

components in the first chromatography step using a SPSephadex C-25 column. The spore-lytic enzyme activity was retarded on a BSA-Sepharose $4 \mathrm{~B}$ column, indicating an affinity between BSA and the enzyme. The affinity was found to be stronger at $4{ }^{\circ} \mathrm{C}$ than at $20^{\circ} \mathrm{C}$. Fractions containing enzyme activity were further purified by $\mathrm{MCI}$ GEL CQK-30S column chromatography and the enzyme was recovered in the major peak of protein (Fig. 2a, curve 1). Fractions comprising this peak contained a single predominant protein with an apparent molecular mass of 24000 , as determined by SDS-PAGE (Fig. 2b, lane 5). The yield of enzyme activity was $17 \cdot 5 \%$. For comparative purposes, components unretarded on a BSA-Sepharose 4B column were also chromatographed on the same column, as shown in curve 2 of Fig. 2(a). The results shown in Fig. 2 indicate that separation of the spore-lytic enzyme from other protein components by a BSASepharose $4 B$ column is a crucial step for purification of the enzyme.

The fraction containing spore-lytic activity, which was obtained by BSA-Sepharose 4B column chromatography, was treated with antiserum raised against the $24 \mathrm{kDa}$ protein as previously described. As shown in Fig. 3, the treatment led to a complete loss of enzyme activity, in parallel with a disappearance of the $24 \mathrm{kDa}$ protein in the BSA-Sepharose 4B column-purified fraction. This strongly supports our view that the $24 \mathrm{kDa}$ protein possesses the spore-lytic activity.

The $\mathrm{N}$-terminal amino acid sequence of the spore-lytic enzyme was determined as FSNQVIQRGASGEKVIELQ (19 residues). We could not find any protein sharing this amino-terminus (computer analysis by using
Genetyx homology search program and the swiss-prot protein database).

Degradation of coat-stripped spores by the enzyme resulted in the release of a large amount of free amino groups $\left(5 \cdot 3 \pm 0 \cdot 3 \mu \mathrm{m} \mathrm{ml}^{-1}\right.$ under the conditions described in Methods) and only a minor amount of reducing groups $\left(0.03 \pm 0.006 \mu \mathrm{m} \mathrm{ml}^{-1}\right)$. No free amino groups and reducing groups were liberated when the enzyme was boiled for $10 \mathrm{~min}$ before the assay. The molar ratio of free amino groups to reducing groups was 175 , suggesting that no cleavage of the cortex polysaccharide had occurred.

\section{Effects of surfactant, temperature, $\mathrm{pH}$, ionic strength and chemicals on spore-lytic enzyme activity}

The spore-lytic enzyme (0.4 units), which was partially purified by a BSA-Sepharose $4 \mathrm{~B}$ column, was used in these experiments.

Besides $\mathrm{C}_{12} \mathrm{E}_{9}$, non-ionic surfactants such as sucrose monolaurate, octyl glucoside and dodecyl polyglucoside (final concn $0.1 \%$ ) were also effective in preventing enzyme inactivation. SDS $(0.02 \%)$, however, inactivated the enzyme.

In contrast to the heat-resistance of the enzyme in situ, the isolated enzyme was completely inactivated after incubation at $60^{\circ} \mathrm{C}$ for $2 \mathrm{~min}$ or $45^{\circ} \mathrm{C}$ for $10 \mathrm{~min}$. Temperature sensitivity of the enzyme in solution is shown in Fig. 4(a).

The $\mathrm{pH}$ dependence of activity of the enzyme in solution 
Table 3. The effects of various chemicals on germination and spore-lytic enzyme activity

Normal spores were incubated in $75 \mu \mathrm{l} 0.25 \mathrm{M}$ sodium phosphate buffer, $\mathrm{pH} 7 \cdot 0$, containing the indicated concentration of chemicals at $32{ }^{\circ} \mathrm{C}$ for $10 \mathrm{~min}$. The above buffer $(75 \mu \mathrm{l})$ containing $20 \mathrm{mM} \mathrm{L}$-alanine and $8 \mathrm{mM}$ adenosine was added to the spore suspension to induce germination. The spore-lytic enzyme ( $15 \mu \mathrm{l}, 0.4$ units) was mixed with $130 \mu \mathrm{l}$ assay medium, to obtain the desired concentration listed. After being incubated at $32{ }^{\circ} \mathrm{C}$ for $10 \mathrm{~min}, 5 \mu \mathrm{l}$ of coat-stripped spores were added and the enzyme activity measured. The final $\mathrm{OD}_{600}$ of these spore suspensions was 0.1 in a cell of $1 \mathrm{~mm}$ light path. Sodium thioglycollate and EDTA were removed from the assay medium when effects of thiol reagents and $\mathrm{ZnCl}_{2}$ were tested. Values are rounded off to integers. These data represent the mean of two (for germination) and three (for lytic activity) independent experiments (SD $<10 \%$ of the mean).

\begin{tabular}{|lccc|}
\hline Chemicals & $\begin{array}{c}\text { Concn } \\
(\mathbf{m M})\end{array}$ & $\begin{array}{c}\text { Inhibition of decrease in } \\
\text { OD }_{600} \mathbf{( \% )}\end{array}$ \\
\cline { 3 - 4 } & & \multicolumn{2}{c|}{$\begin{array}{c}\text { Germination } \\
\text { Spore-lytic } \\
\text { activity }\end{array}$} \\
& & 100 & 0 \\
D-Alanine & 5 & 100 & 0 \\
DFP & 9 & 35 & 0 \\
PSMF & 5 & 100 & 100 \\
HgCl & 1 & 95 & 100 \\
ZnCl & 1 & $-*$ & 36 \\
NAM & $0 \cdot 5$ & 95 & 20 \\
NEM & $0 \cdot 3$ & 100 & 97 \\
PCMB & $0 \cdot 5$ & $-*$ & 31 \\
PNAG & 1 & & \\
\hline
\end{tabular}

* The assay medium contained $5 \%(\mathrm{v} / \mathrm{v})$ DMSO, which is a solubilizer of NAM and PNAG. The medium containing $5 \%$ DMSO inhibited germination, although the enzyme activity was not affected.

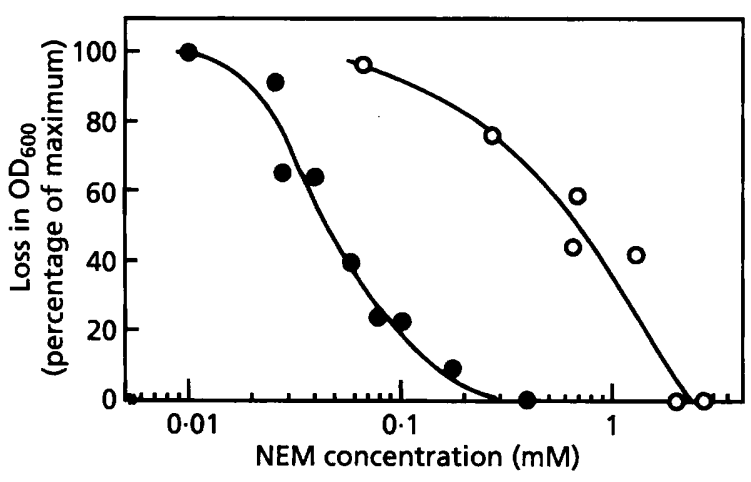

Fig. 5. Effects of NEM on spore-lytic enzyme activity and germination. Germination and spore-lytic enzyme activity were measured at $32{ }^{\circ} \mathrm{C}$, after incubation for $10 \mathrm{~min}$ in the presence of the indicated concentration of NEM, as described in the footnote of Table 3. Values are expressed as a percentage of the decrease in $\mathrm{OD}_{600}$ and are the mean of two determinations (SD $<8 \%$ of the mean). $\bigcirc$, Spore-lytic enzyme activity; $O$, germination. is shown in Fig. 4(b). The enzyme had an optimum at $\mathrm{pH} 7 \cdot 0$. However, optimal germination occurs over a $\mathrm{pH}$ range of $6-9$.

In addition to the effect of ionic strength on the stability of the spore-lytic enzyme shown in Fig. 1, activity of the enzyme depended strongly on the salt concentration of the assay medium. Fig. 4(c) shows the effect of various concentrations of sodium phosphate on enzyme activity. When $\mathrm{NaCl}$ or $\mathrm{KCl}$ was added to a $5 \mathrm{mM}$ solution of sodium phosphate, $\mathrm{pH} 7 \cdot 0$, optimal activity occurred at approx $30 \mathrm{mM}$, with a rapid decrease in activity at both lower and higher salt concentrations.

The effects of a variety of chemicals, including enzyme inhibitors, were examined on spore-lytic activity and germination (Table 3). D-Alanine, a competitive inhibitor of germination, had no effect on the enzyme activity. Serine protease inhibitors such as DFP and PMSF inhibited germination without affecting the spore-lytic enzyme activity, suggesting involvement of serine protease or serine protease-dependent reactions in the germination pathway other than cortex degradation. Although $p$-nitrophenyl- $N$-acetyl- $\beta$-D-glucosamide (PNAG) was not a substrate of the spore-lytic enzyme purified here, partial inhibition of the enzyme with the chemical may be due to structural homology between the spore cortex peptidoglycan and PNAG. Germination and spore-lytic enzyme activity were inhibited with thiol reagents such as $\mathrm{HgCl}_{2}, \mathrm{~N}$-(9-acridinyl)maleimide (NAM), $N$-ethylmaleimide (NEM) and $p$-chloromercuribenzoate (PCMB). Sodium thioglycollate $(10 \mathrm{mM})$ fully reversed the inactivation caused by the mercuric compounds. Fig. 5 shows the effects of NEM on spore-lytic enzyme activity and on germination. The results indicate involvement of multiple sites sensitive to thiol reagents in the germination process of $B$. cereus spores. $\mathrm{ZnCl}_{2}$ inactivated the enzyme, but no effect was observed with $\mathrm{MnCl}_{2}, \mathrm{MgCl}_{2}$ and $\mathrm{CoCl}_{2}$ (1 $\mathrm{mM}$ each).

\section{DISCUSSION}

We have purified a spore-lytic enzyme of molecular mass $24 \mathrm{kDa}$ in an active form from the germination exudate of spores of $B$. cereus IFO 13597 . The solubilized enzyme completely lost its activity when heated at $45^{\circ} \mathrm{C}$ for $10 \mathrm{~min}$ (Fig. 4a). Prior to germination, the spores were extensively washed with $2 \mathrm{M} \mathrm{KCl}$ and $2 \mathrm{M}$ urea, and incubated at $65^{\circ} \mathrm{C}$ for $45 \mathrm{~min}$. It is most likely that the enzyme released into the germination exudate is not a spore surface-bound enzyme, which might have been liberated from the spores or heat-denatured during urea or heat treatment of the spores.

Although the $24 \mathrm{kDa}$ spore-lytic enzyme remains resistant to heat-treatment to which spores are exposed before germination, the enzyme in solution lost its resistance. The enzyme freed from spores was unstable and readily inactivated at low ionic strength. The presence of nonionic surfactants effectively prevented the enzyme from inactivation. It has been indicated that reduction of ionic strength decreases hydrophobic interactions (Kennedy, 
1990) and that non-ionic surfactants bind to hydrophobic regions on the protein without causing an appreciable change in its native structure (Makino, 1979). The enzyme was found to interact with BSA, which possesses binding sites for hydrophobic ligands (Makino, 1979). Taken together, it is reasonable to assume that protection of the hydrophobic surface on the $24 \mathrm{kDa}$ spore-lytic enzyme by association with hydrophobic ligands is of primary importance to maintain the isolated enzyme in its native structure. In situ, the spore-lytic enzyme probably forms a complex with a hydrophobic substance(s), which leads to a stabilization of the enzyme in a spore-bound form. In addition to the proposed hydrophobic interaction, the enzyme activity also depends on ionic strength of the medium (Fig. 4c) and has minimal activity at salt concentrations $>0.1 \mathrm{M}$, at which the enzyme was stabilized. This may imply that the catalytic site of the enzyme is sensitive to an ionic environment, which might be of importance for the formation of the precise threedimensional structure of the site.

The $24 \mathrm{kDa}$ spore-lytic enzyme induced germination-like changes in coat-stripped spores, whereas the enzyme lacked the ability to lyse isolated cortical fragments and isolated cell walls. Such substrate specificities and the sensitivities of the $24 \mathrm{kDa}$ enzyme to temperature, $\mathrm{pH}$, $\mathrm{Hg}^{2+}$ and $\mathrm{Zn}^{2+}$ (Fig. 4a, b and Table 3) are similar to those of a germination-specific $29 \mathrm{kDa}$ spore-lytic enzyme found in spores of B. megaterium KM, which is most probably an amidase-catalysing formation of muramic acid $\delta$-lactam (Foster \& Johnstone, 1987). Our preliminary results showed that exposure of the coat-stripped spores to the $24 \mathrm{kDa}$ enzyme resulted in a release of free amino groups. This suggested that the $24 \mathrm{kDa}$ enzyme is either an amidase or a peptidase. Unfortunately, it is impossible to compare the $24 \mathrm{kDa}$ enzyme with the $29 \mathrm{kDa}$ enzyme on the basis of amino acid alignment, because the sequence of the $29 \mathrm{kDa}$ enzyme is not available. If the $24 \mathrm{kDa}$ enzyme were an amidase, the enzyme would differ from a vegetative cell amidase from B. subtilis (Foster, 1991; Kuroda \& Sekiguchi, 1990), at least, in their $\mathrm{N}$-terminal sequences.

Proteolytic cleavage activates the germination-specific $29 \mathrm{kDa}$ spore-lytic enzyme in B. megaterium KM spores (Foster \& Johnstone, 1988). Similarly, in spores of $B$. cereus $\mathrm{T}$, spore-lytic enzyme activation by release from an inactive bound form has previously been suggested to occur during germination (Gould et al., 1966) and protease inhibitors are known to arrest germination of this organism (Boschwitz et al., 1985, 1991). This implies involvement of proteolytic activity in the germination pathway. The present experiments also suggested involvement of protease in the germination pathway of spores of B. cereus (Table 3). Furthermore, it has been demonstrated that two $\mathrm{Hg}^{2+}$-sensitive sites are involved in the germination process of spores of B. megaterium $\mathrm{KM}$ and that the germination-specific $29 \mathrm{kDa}$ spore-lytic enzyme represents the second sensitive site (Foster \& Johnstone, 1986). The most probable candidates for the $\mathrm{Hg}^{2+}$-sensitive sites are the thiol groups. The results shown in Fig. 5 suggest that, in addition to the $24 \mathrm{kDa}$ spore-lytic enzyme, another thiol reagent-sensitive site must participate in the germination pathway of the $B$. cereus spores studied here. It is apparent that NEM can block germination at a stage prior to the inhibition of the $24 \mathrm{kDa}$ enzyme. This suggests the location of a second $\mathrm{Hg}^{2+}$-sensitive site on the $24 \mathrm{kDa}$ enzyme. Thus, it appears that $B$. cereus IFO 13597 shares a germination mechanism common to $B$. megaterium $\mathrm{KM}$, which was proposed by Foster \& Johnstone (1990). However, there is still much to be elucidated about the details of the germination mechanism. Studies are in progress to solve several questions such as whether a precursor of the $24 \mathrm{kDa}$ enzyme is synthesized, whether modification of the enzyme by protease occurs, and the location of the enzyme in the dormant spore.

\section{ACKNOWLEDGEMENTS}

We thank Dr T. Tsuzuki for generously providing the $\mathrm{Cl}$. perfringens $\mathrm{S} 40$ spores. This research was supported in part by a Grant-in-Aid for Scientific Research (No. 02660083) from the Ministry of Education, Science and Culture of Japan.

\section{REFERENCES}

Ando, Y. (1979). Spore-lytic enzyme released from Clostridium perfringens spores during germination. J Bacteriol 140, 59-64.

Ando, Y. \& Tsuzuki, T. (1984). Energy-dependent activation of spore-lytic enzyme precursor by germinated spores of Clostridium perfringens. Biocbem Biophys Res Commun 123, 463-467.

Boschwitz, H., Halvorson, H. O., Keynan, A. \& Milner, Y. (1985). Trypsin-like enzymes from dormant and germinated spores of Bacillus cereus $\mathrm{T}$ and their possible involvement in germination. J Bacteriol 164, 302-309.

Boschwitz, H., Gofshtein-Gandman, L., Halvorson, H. O., Keynan, A. \& Milner, Y. (1991). The possible involvement of trypsin-like enzymes in germination of spores of Bacillus cereus $\mathrm{T}$ and Bacillus subtilis 168. J Gen Microbiol 137, 1145-1153.

Brown, W. C. \& Cuhel, R. L. (1975). Surface-localized cortex-lytic enzyme in spores of Bacillus cereus 'T. J Gen Microbiol 91, 429-432.

Brown, W. C., Vellom, D., Schnepf, E. \& Greer, C. (1978). Purification of a surface-bound hexosaminidase from spores of Bacillus cereus T. FEMS Microbiol Lett 3, 247-251.

Brown, W. C., Vellom, D., Ho, I., Mitchell, N. \& McVay, P. (1982). Interaction between a Bacillus cereus spore hexosaminidase and specific germinants. J Bacteriol 149, 969-976.

Fields, R. (1972). The rapid determination of amino groups with TNBS. Methods Enzymol 25, 464-468.

Foster, S. J. (1991). Cloning, expression, sequence analysis and biochemical characterization of an autolytic amidase of Bacillus subtilis 168 trpC2. J Gen Microbiol 137, 1987-1998.

Foster, S. J. \& Johnstone, K. (1986). The use of inhibitors to identify early events during Bacillus megaterium KM spore germination. Biochem J 237, 865-870.

Foster, S. J. \& Johnstone, K. (1987). Purification and properties of germination-specific cortex-lytic enzyme from spores of Bacillus megaterium KM. Biochem J 242, 573-579.

Foster, S. J. \& Johnstone, K. (1988). Germination-specific cortexlytic enzyme is activated during triggering of Bacillus megaterium KM spore germination. Mol Microbiol 2, 727-733. 
Foster, S. J. \& Johnstone, K. (1990). Pulling the trigger: the mechanism of bacterial spore germination. Mol Microbiol 4, 137-141.

Gombas, D. E. \& Labbe, R. G. (1981). Extraction of spore-lytic enzyme from Clostridium perfringens spores. J Gen Microbiol 126, 37-44.

Gombas, D. E. \& Labbe, R. G. (1985). Purification and properties of spore-lytic enzymes from Clostridium perfringens type A spores. J Gen Microbiol 131, 1487-1496.

Gould, G. W., Hitchins, A. D. \& King, W. L. (1966). Function and location of a Germination Enzyme in spores of Bacillus cereus. J Gen Microbiol 44, 293-302.

Groves, W. E., Davis, F. C., Jr \& Sells, B. H. (1968). Spectrophotometric determination of microgram quantities of protein without nucleic acid interference. Anal Biochem 22, 195-210.

Kennedy, B. M. (1990). Hydrophobic chromatography. Methods Enzymol 182, 339-343.

Kuroda, A. \& Sekiguchi, J. (1990). Cloning, sequencing and genetic mapping of a Bacillus subtilis cell wall hydrolase gene. J Gen Microbiol 136, 2209-2216.

Laemmli, U. K. (1970). Cleavage of structural proteins during the assembly of the head of bacteriophage T4. Nature 227, 680-685.
Makino, S. (1979). Interaction of proteins with amphiphilic substances. Adv Biopbys 12, 131-184.

Oakley, B. R., Kirsch, D. R. \& Morris, N. R. (1980). A simplified ultrasensitive silver stain for detecting proteins in polyacrylamide gels. Anal Biochem 105, 361-363.

Park, J. \& Johnson, M. (1949). A submicrodetermination of glucose. $J$ Biol Chem 181, 149-151.

Tang, S. S. \& Labbe, R. G. (1987). Mode of action of Clostridium perfringens initiation protein (spore-lytic enzyme). Ann Inst Pasteur Microbiol 138, 597-608.

Tomida, M., Suwa, N., Machida, H., Nishimura, A. \& Makino, S. (1991). Inhibition of germination of Bacillus stearotbermophilus spores by sucrose monoalkylates and other surfactants. Nippon Shokubin Kogyo Gakkaishi 38, 1044-1049.

Warth, A. D. (1972). Action of spore lytic enzymes on the cortex. In Spore $V$, pp. 28-34. Edited by H. O. Halvorson, R. Hanson \& L. L. Campbell. Washington, DC: American Society for Microbiology.

Received 27 July 1993; revised 1 November 1993; accepted 31 December 1993. 